The following group of letters concerns the death of Terri Schiavo in 2005. Because of an editorial oversight, these letters were not published last year, and it seemed appropriate to include them here.

\section{Terri Schiavo: Rest in peace}

As Charles Weijer has pointed out, the case of Terri Schiavo involved a family conflict regarding end-of-life decisionmaking. ${ }^{1}$ This irreconcilable conflict resulted in a series of judicial interventions that were a rerun, with some differences, of the Karen Ann Quinlan, Nancy Beth Cruzan and other wellknown cases.

Nowadays, many hospitals rely on clinical ethicists, ethics committees or mediators - before court intervention - to resolve conflicts in which family members or health care providers disagree about clinical interventions or care plans for an incapacitated patient. What was striking in Terri Schiavo's case was the political rhetoric that surfaced on an issue that health care providers and ethics committees tackle on a daily basis. And what was so tragic, aside from the patient's condition, was the breach of her right to die with dignity.

Whatever one's view of her case, Terri Schiavo had a right to have her life and death kept private and her medical records held in confidence. The media, along with prominent politicians, paraded her medical status for the entire world to witness. Not only was there a breach of privacy, but politicians, the media, special interest groups, family members and supporters used her mental status to promote their causes.

If one believes that withdrawing nutrition and hydration from a patient in an irreversible coma or persistent vegetative state constitutes murder, there are ways of debating the issue and developing a consensus. But to use Terri Schiavo and her husband, her legally appointed surrogate decision-maker, to further that point of view strikes me as opportunistic. The violation of the Kantian principle to treat mankind as an end, never as a means, dealt a further blow to Terri Schiavo's wish to die with dignity. May she finally rest in peace.

\section{Joseph Erban}

Member, Clinical Ethics Committee Sir Mortimer B. Davis-Jewish General Hospital

Montréal, Que.

\section{REFERENCE}

I. Weijer C. A death in the family: Reflections on the Terri Schiavo case [editorial]. CMAJ 2005;172(9): II97-8.

DOI:I0.I503/cmaj.I050III

The analysis by Glenys Godlovitch and associates $^{1}$ of discontinuing life support is well done. It is, however, important to remember that under the Canadian Constitution, it is the provinces (not the federal government) that have jurisdiction with regard to substitute health care decision-making. Therefore, readers should be aware that the Alberta court decision discussed by these authors may not apply in other provinces, where the laws may be different.

Although the common law $^{2}$ has long recognized the legal validity of living wills (instructional advance directives), the statutory enactments in some provinces may require that certain procedural steps be taken before they become enforceable. Even without these steps, the instructional advance directive is evidence of the person's wishes. Although, as Weijer ${ }^{3}$ rightfully points out, the instructional advance directive is not a panacea, such a directive is worth writing to provide guidance to surrogate decision-makers in situations such as the withdrawal of life support if the patient becomes comatose.

\section{William J. Sullivan}

Barrister and Solicitor

Vancouver, BC

\section{REFERENCES}

I. Godlovitch G, Mitchell I, Doig CJ. Discontinuing life support in comatose patients: an example from Canadian case law. CMAJ 2005;I72(9):II72-3.

2. Malettev. Shulman (I990), 72 O.R. (2d) 4 I7.

3. Weijer C. A death in the family: Reflections on the Terri Schiavo case [editorial]. CMAJ 2005;I72(9): II97-8.

DOI:I0.I503/cmaj.I050108
Charles Weijer's commentary on the death of Terri Schiavo ${ }^{1}$ represents opinion not based on fact. Terri Schiavo did not require "the provision of artificial nutrition and hydration" any more than any immature or dependent person requires food and water with the aid of someone who cares for them. If her nutrition was "artificial," then so it is for many patients in hospital, some people with disabilities, and children too young to feed themselves.

Terri Schiavo was not a burden to anybody. Her parents were quite content to provide all she needed. What was startling, in fact astonishing, to all people who love life, was that the judges would not allow her parents to care for her, but enabled medical staff to starve her to death, a lingering and painful way to die. There is nothing noble in this.

\section{Philip G. Ney}

Adult and Family Psychiatrist

Victoria, BC

\section{REFERENCE}

I. Weijer C. A death in the family: Reflections on the Terri Schiavo case [editorial]. CMAJ 2005;172(9): II97-8.

DOI:I0.1503/cmaj.I050134

\section{[Dr. Weijer responds:]}

The purpose of my commentary ${ }^{1}$ was to disagree with those who suggest that living wills are a moral panacea. Although living wills are an important means by which people express their wishes for future treatment, they seem an unlikely solution for cases like that of Terri Schiavo. People in their teens and 20 s are unlikely to complete living wills. Even if a living will is in place, a deeply divided family will disagree as to its meaning. As a result, physicians need to employ techniques of communication, negotiation and mediation to keep families united in making decisions for loved ones whenever possible.

Erban is critical of how Terri Schiavo's plight was unduly publicized by political conservatives and the media, pointing out that the resulting frenzy was an affront to her dignity. I agree.

Sullivan concurs that living wills are not a panacea, but points out that they 
are generally useful. He is right that "it is worth writing [a living will] to provide guidance to surrogate decisionmakers" and, I would add, health care providers.

Ney disagrees with my position, labelling it "opinion not based in fact." The removal of artificial nutrition and hydration from patients evokes strong reactions because people have differing values. Some believe that one has an obligation to preserve life. Others, perhaps the majority of Canadians, believe that an individual's right of privacy is more important. I have written elsewhere that the values of those with religious or cultural reasons to preserve life in a persistent vegetative state ought to be respected. ${ }^{2}$ But tolerance is a 2 -way street. Terri Schiavo did not share the conservative Catholic views of her parents and told her husband "I don't want to be kept alive on a machine." Terri Schiavo's values and choices are just as worthy of respect as those who would choose differently for themselves.

\section{Charles Weijer}

Associate Professor of Bioethics, Medicine and Surgery

Dalhousie University

Halifax, NS

\section{REFERENCES}

I. Weijer C. A death in the family: Reflections on the
Terri Schiavo case [editorial]. CMAJ 2005:172(9): II $97-8$.

2. Weijer C. Cardiopulmonary resuscitation for patients in a persistent vegetative state: Futile or acceptable? [editorial]. CMAJ I998;158:49I-3.

DOI:I0.1503/cmaj.I050I75

\section{Corrections}

In a news brief ${ }^{1}$ about the new Canadian Cardiovascular Atlas, the online link is incorrectly stated. It should be www.ccort.ca. We apologize for any inconvenience this may have caused.

\section{REFERENCE}

I. Sibbald B. News @ a glance. CMAJ 2006;175(3):237. DOI:10.1503/cmaj.061070

In a recent Clinical Vistas Brief, ${ }^{1}$ the title of the article was changed in error from Dextrocardia with situs solitus to Dextrocardia with sinus solitus. We apologize for our mistake. article. All letters will be considered for publication in the print journal.

Letters written in response to an article published in $C M A J$ are more likely to be accepted for print publication if they are submitted within 2 months of the article's publication date. Letters accepted for print publication are edited for length (usually 250 words) and house style.

\section{Mécanisme de présentation des lettres}

Le site amélioré des lettres du JAMC est désormais le portail de réception de tous les textes destinés à la chronique Lettres. Pour rédiger une lettre, consultez un article sur le site www.jamc.ca et cliquez ensuite sur le lien «Lettres électroniques : répondre à cet article», dans la boîte en haut à droite de l'article. Toutes les lettres seront étudiées pour une éventuelle publication dans le journal imprimé.

Les lettres répondant à un article publié dans le JAMC sont plus susceptibles d'être acceptées pour publication imprimée si elles sont présentées dans les deux mois de la date de publication de l'article. Les lettres acceptées pour publication imprimée sont révisées en fonction du style du JAMC et raccourcies au besoin (elles doivent habituellement compter au maximum 250 mots).

\section{REFERENCE}

I. Leung AKC, Robson WLM. Dextrocardia with sinus solitus. $C M A J 2006 ; 175(3): 244$.

DOI:I0.1503/cmaj.o6ro7I

In a recent Clinical Vista, ${ }^{1}$ one of the authors' names was spelled incorrectly. The correct spelling is Alyson Shaw. We regret the error.

\section{REFERENCE}

I. Albedwawi S, LeBlanc C, Show A, Slinger RW. A I75(4):354.

DOI:I0.1503/cmaj.061083 teenager with fever, rash and arthritis. CMAJ 2006; 